\title{
THE RELATIONSHIP OF THE STUDENTS' PERCEPTION ON THE CAMPUS LEARNING ENVIRONMENT AND THEIR GPA IN SCHOOL OF MEDICINE OF MULAWARMAN UNIVERSITY
}

\author{
Achmad Ferdinan Amrullah ${ }^{1}$, Sulistiawati ${ }^{2}$, dan Cicih Bhakti Purnamasari ${ }^{3}$ \\ ${ }^{1}$ Medicine Study Program, School of Medicine, Mulawarman University, Indonesia \\ ${ }^{2}$ Laboratory of Medical Education, School of Medicine, Mulawarman University, Indonesia \\ ${ }^{3}$ Laboratory of Medical Education, School of Medicine, Mulawarman University, Indonesia \\ *E-mail: amrullahachmad@yahoo.co.id
}

\begin{abstract}
The success of the student learning process is characterized by academic achievement. One of the factors that can affect academic achievement is the learning environment. This study aims to determine the relationship of the students' perception on the campus learning environment and their GPA in school of medicine of Mulawarman University. This research is an observational analytic study with cross sectional method. The research respondents were students of the Medicine Study Program of the School of Medicine in Mulawarman University by using total sample technique. The method of data analysis used descriptive data analysis and the analytic data analysis used chi square test. There were 316 respondents who met the inclusion and exclusion criteria, male respondents were 91 people $(28.8 \%)$ and female respondents were 225 people (71.2\%). As many as 268 students $(84.8 \%)$ had more positive than negative perception on the campus learning environment, while as many as 232 students $(73.4 \%)$ got good category for the grade point. The results of the study obtained $p=0.000$. In conclusion, there is a relationship between student perceptions of the learning environment on campus with an grade point.
\end{abstract}

Keyword: learning environment, Grade Point Average (GPA), medicine student

\section{INTRODUCTION}

Learning is a process of behavior that is build through practice or experience. Learning is a process, not an outcome ${ }^{1}$. The success of learning are influenced by internal factors, such as characteristics of students, learning attitude, motivation to learn, learning concentration, processing of learning, exploring the result of learning, self-confidence and learning habits ${ }^{2}$. The success of learning is also influenced by external factors, such as the learning environment which includes the family environment, school environment, and community environment. Other external factors are the attitude of parents towards children and the attitude of lecturers towards students ${ }^{3}$. The learning environment is a condition and all facilities used for daily learning activities. The learning environment is an aspect that can be used as a reference for the realization of a good teaching and learning process. A good learning environment can improve student achievement which is manifested in student learning outcomes. The learning environment includes: family environment, school/campus environment, as well as the community environment that can affect the daily lives of students in pursuing their education, especially in an effort to improve their learning achievement better than before ${ }^{4}$. Students' academic success is marked by academic achievements shown through the grade point (GP) and grade point average (GPA). Students are required to compete in obtaining academic achievements during lectures, 
with the benchmark being the grade point. The better the academic mastery of students, the better the achievements obtained ${ }^{5}$. A conducive learning environment can affect student learning achievement which is increasing, because if students feel comfortable doing the teaching and learning process on their own campus, then the enthusiasm to complete their lectures becomes higher, it can affect the learning outcomes better by itself ${ }^{6}$.

There are several studies linking the learning environment to learning achievement. Previous studies showed a positive and significant correlation between the learning environment with academic achievement. The learning environment not only influences academic achievement directly but also can affect qualitative learning outcomes ${ }^{7}$. Other studies show a significant relationship between the perception of nursing students on the learning environment with learning outcomes. The results of study would significantly better when the perception of most students on the learning activities in accordance with their learning environment like ${ }^{8}$.

Other studies that do show a positive relationship between the level of perception of medical students on the learning environment with their academic achievement. Students who have good academic performance are satisfied with their learning environment, on the other hand, students who are still not satisfied academically, feel less satisfied with their learning environment ${ }^{9}$. Studies on medicine students show the influence of the clinical learning environment of medicine students' academic achievement. The learning environment at the School of Medicine has an impact on values, actions, professional concepts, and the development of a student's professional identity ${ }^{10}$. Other studies have shown a positive and significant relationship between the learning environment and student learning achievement. Intelligence is not the only determinant of student academic achievement. Academic achievement of a student is always associated with many components of the learning environment ${ }^{4}$. Studies on obstetrics students show there is no significant relationship between the learning environment and academic achievement ${ }^{11}$.

\section{MATERIAL AND METHOD}

This study is an observational analytic study with cross sectional method that aimed to determine the relationship of the students' perception on the campus learning environment and the grade point in school of medicine of Mulawarman University from February to April 2019. The sample consisted of 316 people who were chosen based on primary data collected by researchers through filling the questionnaire, questionnaires were used to assess the perception of the environment of learning that is Dundee Ready Educational Environment Measure (DREEM) questionnaire and the data of secondary that is obtained from students' grade point data in the first semester of the 2018/2019 academic year derived from the Academic Sub-Division of School of Medicine of Mulawarman University. Data processing was carried out by using Microsoft Word 2016 software, Microsoft Excel 2016, and IBM SPSS 23.

\section{RESULTS AND DISCUSSION}

This research was conducted at the School of Medicine in Mulawarman University. School of Medicine in Mulawarman University is one of the faculties with B accreditation, located on Jalan Krayan, Mt. Kelua, North Samarinda, Samarinda City, East Kalimantan. Data collection was carried out on 27 February 2019 to 15 April 2019. This research was conducted at the School of Medicine in Mulawarman University which consisted of 4 batches, such as first year (2018), sophomore (2017), third year (2016), and final year (2015). Data is collected by adjusting the academic schedule of each batch in the Lecture Room (LR) in the campus of School of Medicine in Mulawarman University. 
Received :2019-11-11 Revised : 2020-01-06 Acceptance : 2020-01-24 Publish : 2020-06-05

Table 1. Characteristics of Respondents by Gender

\begin{tabular}{|c|c|c|}
\hline \multicolumn{2}{|c|}{ Gender } & \multirow[b]{2}{*}{$\begin{array}{l}\text { Total } \\
\mathrm{n}(\%)\end{array}$} \\
\hline $\begin{array}{l}\text { Male } \\
\mathrm{n}(\%)\end{array}$ & $\begin{array}{c}\text { Female } \\
\mathrm{n}(\%)\end{array}$ & \\
\hline $91(28.8)$ & $225(71.2)$ & $316(100)$ \\
\hline
\end{tabular}

\section{Source: Primary Data, 2019}

Based on the results of research that has been conducted using analytic observational study with cross sectional method. Respondents that meet the criteria for inclusion and exclusion of as many as 316 students of Medicine study program, School of Medicine, Mulawarman University. The obtained data were in the form of primary data from the questionnaire responses and the data secondary data was from the Academic Sub-Division and Students and Alumni Sub-Division of School of Medicine in Mulawarman University. Characteristics of respondents based on the gender is dominated by woman as much as 225 students $(71.2 \%)$.

Table 2. The Frequency of Students Perceptions on Learning Environment at School of Medicine, Mulawarman University in 2019

\begin{tabular}{|c|c|c|c|c|c|}
\hline \multirow[b]{2}{*}{ Respondent } & \multicolumn{4}{|c|}{ Learning Environment } & \multirow[b]{2}{*}{$\begin{array}{l}\text { Total } \\
\text { n (\%) }\end{array}$} \\
\hline & $\begin{array}{l}\text { Very } \\
\text { Bad } \\
\mathrm{n}(\%)\end{array}$ & $\begin{array}{l}\text { Lots of } \\
\text { Issues } \\
\mathrm{n}(\%)\end{array}$ & $\begin{array}{c}\text { More Positive } \\
\text { than Negative } \\
n(\%)\end{array}$ & $\begin{array}{c}\text { Very Good } \\
\text { n (\%) }\end{array}$ & \\
\hline 2015 & $0(0)$ & $7(8.8)$ & $71(88.8)$ & $2(2.5)$ & $80(100)$ \\
\hline 2016 & $0(0)$ & $2(2.7)$ & $72(96.0)$ & $1(1.3)$ & $75(100)$ \\
\hline 2017 & $0(0)$ & $4(4.8)$ & $72(86.7)$ & $7(8.4)$ & $83(100)$ \\
\hline 2018 & $0(0)$ & $22(28.2)$ & $53(67.9)$ & $3(3.8)$ & $78(100)$ \\
\hline Total & $0(0)$ & $35(11.1)$ & $268(84.8)$ & $13(4.1)$ & $\begin{array}{c}316 \\
(100)\end{array}$ \\
\hline
\end{tabular}

Source: Primary Data, 2019

The results of the 316 respondents of the Medicine Study Program of the School of Medicine of Mulawarman University show that majority of students' perception, as many as 268 students $(84.8 \%)$, on their learning environment fall into more positive than negative category. The learning environment on campus is one of the factors that can increase student achievement and is a reflection of the students' potential who are influenced by the quality of the teaching and learning process. In the teaching and learning process, there are at least three elements that are very influential, such as the quality of lecturers, curriculum and targets as well as infrastructure including laboratories ${ }^{12}$. When it is connected to the result of analysis that have been obtained, it means the quality of lecturers, curriculum and targets as well as infrastructure including laboratories can support the learning environment of students on campus. 
Table 3. The Analysis on 35 Students of Medicine Study Program of School of Medicine of Mulawarman University whose Perception is that Learning Environment on Campus Has Lots of Issues in 2019

\begin{tabular}{|c|c|c|c|c|c|c|c|}
\hline \multirow[b]{2}{*}{ Sub-Scale } & \multirow[b]{2}{*}{ Statement } & \multicolumn{5}{|c|}{ Assessment } & \multirow[b]{2}{*}{$\begin{array}{l}\text { Total } \\
\text { n (\%) }\end{array}$} \\
\hline & & $\begin{array}{c}\text { Strongly } \\
\text { Disagree } \\
\mathrm{n}(\%)\end{array}$ & $\begin{array}{l}\text { Disagree } \\
\text { n (\%) }\end{array}$ & $\begin{array}{c}\text { Undecided } \\
\text { n (\%) }\end{array}$ & $\begin{array}{l}\text { Agree } \\
\text { n (\%) }\end{array}$ & $\begin{array}{l}\text { Strongly } \\
\text { Agree } \\
\mathrm{n}(\%)\end{array}$ & \\
\hline \multirow{2}{*}{$\begin{array}{l}\text { Students' Perception } \\
\text { on Learning Process }\end{array}$} & Positive & $0(0,0)$ & $0(0,0)$ & $0(0,0)$ & $16(45,7)$ & $19(54,3)$ & $\begin{array}{c}35 \\
(100,0)\end{array}$ \\
\hline & Negative & $21(60,0)$ & $14(40,0)$ & $0(0,0)$ & $0(0,0)$ & $0(0,0)$ & $35(100)$ \\
\hline \multirow{2}{*}{$\begin{array}{l}\text { Student Perceptions } \\
\text { on Lecturers }\end{array}$} & Positive & $0(0,0)$ & $0(0,0)$ & $0(0,0)$ & $24(68,6)$ & $11(31,4)$ & $\begin{array}{c}35 \\
(100,0) \\
\end{array}$ \\
\hline & Negative & $19(54,3)$ & $16(45,7)$ & $0(0,0)$ & $0(0,0)$ & $0(0,0)$ & $\begin{array}{c}35 \\
(100,0)\end{array}$ \\
\hline \multirow{2}{*}{$\begin{array}{l}\text { Students' Social } \\
\text { Perception }\end{array}$} & Negative & $25(71,4)$ & $9(25,7)$ & $1(2,9)$ & $0(0,0)$ & $0(0,0)$ & $\begin{array}{c}35 \\
(100,0)\end{array}$ \\
\hline & Positive & $0(0,0)$ & $0(0,0)$ & $2(5,7)$ & $15(42,9)$ & $18(51,4)$ & $\begin{array}{c}35 \\
(100,0)\end{array}$ \\
\hline \multirow{2}{*}{$\begin{array}{l}\text { Students' Perception } \\
\text { on Academic }\end{array}$} & Positive & $22(62,9)$ & $10(28,6)$ & $3(8,5)$ & $0(0,0)$ & $0(0,0)$ & $\begin{array}{c}35 \\
(100,0)\end{array}$ \\
\hline & Negative & $0(0,0)$ & $0(0,0)$ & $3(8,6)$ & $3(8,6)$ & $29(82,8)$ & $\begin{array}{c}35 \\
(100,0) \\
\end{array}$ \\
\hline \multirow{2}{*}{$\begin{array}{l}\text { Students' Perception } \\
\text { on the Atmosphere } \\
\text { of the Campus }\end{array}$} & Negative & $0(0,0)$ & $0(0,0)$ & $0(0,0)$ & $10(28,6)$ & $25(71,4)$ & $\begin{array}{c}35 \\
(100,0)\end{array}$ \\
\hline & Positive & $26(74,3)$ & $9(25,7)$ & $0(0,0)$ & $0(0,0)$ & $0(0,0)$ & $\begin{array}{c}35 \\
(100,0)\end{array}$ \\
\hline
\end{tabular}

Source: Primary Data, 2019

Nevertheless, there are still some students who think the learning environment on campus has lots of issues. There were 35 students $(11.1 \%)$ whose perception on learning environment in campus has lots of issues and majority came from Batch 2018.

Table 4. The Frequency of Students' Grade Point of School of Medicine of Mulawarman University in 2019

\begin{tabular}{ccccccc}
\cline { 3 - 5 } & \multicolumn{9}{c}{ Grade Point } & \\
\cline { 2 - 5 } Respondent & $\begin{array}{c}\text { Very Good } \\
\mathrm{n}(\%)\end{array}$ & $\begin{array}{c}\text { Good } \\
\mathrm{n}(\%)\end{array}$ & $\begin{array}{c}\text { Moderate } \\
\mathrm{n}(\%)\end{array}$ & $\begin{array}{c}\text { Low } \\
\mathrm{n}(\%)\end{array}$ & $\begin{array}{c}\text { Very Low } \\
\mathrm{n}(\%)\end{array}$ & $\begin{array}{c}\text { Total } \\
\mathrm{n}(\%)\end{array}$ \\
\hline 2015 & $0(0)$ & $51(63.8)$ & $29(36.3)$ & $0(0)$ & $0(0)$ & $80(100)$ \\
2016 & $0(0)$ & $67(89.3)$ & $8(10.7)$ & $0(0)$ & $0(0)$ & $75(100)$ \\
2017 & $0(0)$ & $75(90.4)$ & $8(9.6)$ & $0(0)$ & $0(0)$ & $83(100)$ \\
2018 & $0(0)$ & $39(50)$ & $39(50)$ & $0(0)$ & $0(0)$ & $78(100)$ \\
Total & $0(0)$ & $232(73.4)$ & $84(26.6)$ & $0(0)$ & $0(0)$ & $316(100)$ \\
\hline
\end{tabular}

Source: Secondary Data, 2019

Grade point of students of the Medicine Study Program at Mulawarman University consists of several categories, such as very good, good, moderate, low, and very low. Overall, 232 students (73.4\%) got good grade point. Theoretically, learning outcomes are influenced by internal factors and external factors. Internal factors that can influence learning outcomes are exercise and success, association, 
readiness of learning, physiological readiness, intelligence, interests and effort ${ }^{13}$. External factor that can affect learning outcomes is learning environment which is divided into three categories; campus environment, family environment and community environment ${ }^{11}$. If these factors are connected to the results of the analysis of students' grade point, one of them can support student learning outcomes, therefore, according to the table above, the majority of grade point of students of the Medicine Study Program at Mulawarman University are in good category.

Table 5. The Result of Cross Tabulation of Students' Perception on the Learning Environment with Students Grade Point in the School of Medicine, Mulawarman University in 2019

\begin{tabular}{|c|c|c|c|c|}
\hline \multirow{2}{*}{$\begin{array}{l}\text { Perception on } \\
\text { Learning } \\
\text { Environment }\end{array}$} & \multirow[b]{2}{*}{ Respondent } & \multicolumn{2}{|c|}{ Grade Point } & \multirow[b]{2}{*}{$\begin{array}{l}\text { Total } \\
\text { n (\%) }\end{array}$} \\
\hline & & $\begin{array}{l}\text { Good } \\
\text { n (\%) }\end{array}$ & $\begin{array}{c}\text { Moderate } \\
\text { n (\%) }\end{array}$ & \\
\hline \multirow{5}{*}{ Lots of Issues } & 2015 & $0(0,0)$ & $7(100,0)$ & $7(100,0)$ \\
\hline & 2016 & $2(100,0)$ & $0(0,0)$ & $2(100,0)$ \\
\hline & 2017 & $2(50,0)$ & $2(50,0)$ & $4(100,0)$ \\
\hline & 2018 & $0(0,0)$ & $22(100,0)$ & $22(100,0)$ \\
\hline & Total & $4(11,4)$ & $31(88,6)$ & $35(100,0)$ \\
\hline \multirow{5}{*}{$\begin{array}{l}\text { More Positive } \\
\text { than Nerative }\end{array}$} & 2015 & $51(71,8)$ & $20(28,2)$ & $71(100,0)$ \\
\hline & 2016 & $64(88,9)$ & $8(11,1)$ & $72(100,0)$ \\
\hline & 2017 & $68(94,4)$ & $4(5,6)$ & $72(100,0)$ \\
\hline & 2018 & $38(71,7)$ & $15(28,3)$ & $53(100,0)$ \\
\hline & Total & $221(82,5)$ & $47(17,5)$ & $268(100,0)$ \\
\hline \multirow{5}{*}{ Very Good } & 2015 & $0(0,0)$ & $2(100,0)$ & $2(100,0)$ \\
\hline & 2016 & $1(100,0)$ & $0(0,0)$ & $1(100,0)$ \\
\hline & 2017 & $5(71,4)$ & $2(28,6)$ & $7(100,0)$ \\
\hline & 2018 & $1(33,3)$ & $2(66,7)$ & $3(100,0)$ \\
\hline & Total & $7(53,8)$ & $6(46,2)$ & $13(100,0)$ \\
\hline
\end{tabular}

Table 6. The Significance Value of the Relationship between Students' Perceptions on the Learning Environment in Campus with Students' GPA in Medicine Study Program, School of Medicine,

Mulawarman University in 2019

\begin{tabular}{ccccc}
\hline \multicolumn{5}{c}{ P Value } \\
& & & \\
\hline Class of 2015 & Class of 2016 & Class of 2017 & Class of 2018 & All \\
\hline 0,000 & 1,000 & 0,007 & 0,000 & 0,000 \\
\hline
\end{tabular}

The results of analysis of respondents as a whole showed a relationship between students' perceptions on the learning environment in campus with their GPA. Likewise, the results of the analysis in each class, such as the class of 2015, 2017 and 2018, a relationship between students' perceptions on the learning environment in campus with their GPA. This is in line with the result of previous study that there is a significant relationship between nursing students' perceptions on the learning environment with their learning outcomes. Their learning outcomes are significantly better when students' perceptions of learning activities are in accordance with the learning environment that they like ${ }^{8}$. This is also in line with other research which shows a positive relationship between the level of perception 
of medicine students on the learning environment with their academic achievement. Students who have good academic performance are satisfied with their learning environment, on the other hand, students who are still unsatisfied academically, feel less satisfied with their learning environment ${ }^{9}$.

A conducive learning environment can affect student's learning achievement. If students feel comfortable doing the teaching and learning process in their own campus, the enthusiasm of the student in completing their lecture would be higher. This can affect the learning outcomes which would be better $^{6}$. To achieve successful learning, they should be supported by learning environment that includes family, school/campus and community environment that provides a range of facilities in order to improve the achievement of students ${ }^{4}$.

The results of the analysis of class of 2016 found that there is no relationship between the students perception on learning environment in their campus with the GPA of Medicine Study Program students, at School of Medicine, Mulawarman University. The results of the analysis is not in line with the result of the analysis of class of 2015, 2017, and 2018 and is not in accordance with some theories which state that the environment learned that the ideal can be influential on the result of learning that more and more good ${ }^{6}$. The learning environment consists of the family environment, the school/campus environment, and the community environment. Said factors have important roles in encouraging students to improve their learning achievement ${ }^{4}$.

However, there is a previous study with similar result that stated that there was no significant relationship between the learning environment with the learning achievement ${ }^{11}$. The process of change can occur from unable to able during certain period. Their improvement, especially in the pattern of behavior indicates that the process of learning has occurred. The more they gain personal abilities, the better they get and improve themselves. Abilities that can be categorize as cognitive includes knowledge and understanding, the ability of sensory-psychomotor includes skills to perform a series of movements in certain order, and the ability of dynamic-affective which includes attitudes and value, which permeates the behavior and actions. The result of learning is the ability of someone who has experienced the process of learning. Results of learning as something that is acquired, obtained or controlled after the process of learning which usually can be shown with a score or value ${ }^{12}$.

A good learning achievement can encourage students to be persevering and diligent in studying. To achieve a successful of learning, the student is assisted and supported by a suitable learning environment that includes family environment, school/campus environment, and community environment that provide a wide range of facilities in order to increase students' learning achievement ${ }^{4}$. Factors that may affect students' learning achievement are divided into two categories, such as internal and external. Internal factors that can affect the outcome of learning such as intelligence, physiological, readiness to learn, the association of exercises and success, interest and effort, meanwhile, external factors that can affect the outcome of learning environment that includes family environment, school/campus environment, and community environment ${ }^{13}$. Insignificant relationships that occur on students of class 2016 might be caused by several factors that might affect the GPA, in addition to the learning environment, learning such as intelligence, physiological, readiness to learn, the association of exercises and success, interest and effort ${ }^{13}$.

\section{CONCLUSION}

Based on the results of the study, it can be concluded that:

1) Majority of students' perceptions on the learning environment in campus are in the more positive than negative category $(84.8 \%)$.

2) Grade point (GP) of students of the Medicine Study Program of the School of Medicine, Mulawarman University mostly are in the good category (73.4\%).

3) There is a relationship between students' perceptions on the learning environment in campus and the students' GPA. 


\section{REFERENCES}

1. Nidawati. (2013). Belajar Dalam Perspektif Psikologi dan Agama. Pionir, 1 (1), 13-28.

2. Daryanti, M. S. (2016). Hubungan Lingkungan Belajar dengan Prestasi Belajar Mahasiswa. Jurnal Kebidanan dan Keperawatan, 12 (1), 84-89.

3. Yuzarion. (2017). Faktor yang Mempengaruhi Prestasi Belajar Peserta Didik. Ilmu Pendidikan, 2 (1), 107-117.

4. Nisa, Y. (2017). Faktor-Faktor Eksterna yang Mempengaruhi Prestasi Belajar Mahasiswa. Jurnal Edunomic, 5 (2), 76-88.

5. Daruyani, S. (2013). Faktor-Faktor yang Mempengaruhi Indeks Prestasi Mahasiswa FSM Universitas Diponegoro Semester Pertama Dengan Metode Regresi Logistik Biner. 12(1), 12-23.

6. Santoso, A. B. (2018). Peningkatan Prestasi Belajar Mahasiswa dengan Menciptakan Lingkungan Belajar yang Kondusif . Jurnal Muara Ilmu Sosial, Humaniora, dan Seni, 2 (1), 52-59.

7. Lizzio, A. (2002). University Students' Perceptions of the Learning Environment and Academic Outcomes: Implications for theory and practice. Studies in Higher Education, 27 (1), 27-52.

8. Yeh, T.-K. (2016). Effects of Congruence Between Preferred and Perceived Learning Environments in Nursing Education in Taiwan: a Cross-Sectional study. BMC Medical Education, $6(1), 1-8$.

9. Colbert-Getz, J. M. (2016). Does Academic Performance or Personal Growth Share a Stronger Association with Learning Environment Perception? International Journal of Medical Education, 7, 274-278.

10. Fleit, H. B. (2017). A Model of Influences On The Clinical Learning Environment: the Case For Change at One U.S. Medical School. BMC Medical Education, 17, 63-67.

11. Malasari, R. B. (2017). Hubungan Lingkungan dan Motivasi Belajar dengan Prestasi Belajar Mahasiswa Akademi Kebidanan Berlian Nusantara Magetan. IJMS - Indonesian Journal On Medical Science, 4 (2), 170-176.

12. Likumahwa, F. M. (2018). Analisis Faktor-faktor yang Mempengaruhi Indeks Prestasi Mahasiswa dengan Metode Analisis Faktor Dan Analisis Diskriminan. Seminar Nasional IENACO , 529-537.

13. Husamah, Pantiwati, Y., Restian, A., \& Sumarsono, P. (2016). Belajar \& Pembelajaran. Malang: Universitas Muhammadiyah Malang. 